\title{
SELF-REGULATED LEARNING IN CONSTRUCTIVIST APPROACH BASED SCIENCE LABORATORY PRACTICES AND OPINIONS ON CONSTRUCTIVIST APPROACH
}

\author{
Emine Erdem, Sinem Dinçol Özgür, Zeki Bayram, \\ Özge Özyalçın Oskay, Şenol Şen \\ Hacettepe University,Ankara, Turkey \\ E-mail: erdeme@hacettepe.edu.tr, sinemdincol@gmail.com, \\ zeki.bayramm@gmail.com, ozge@hacettepe.edu.tr, schenolschen@gmail.com
}

\begin{abstract}
With this study, it was aimed to determine the effect of constructivist chemistry laboratory on science and technology pre-service teachers'opinions about constructivist approach and their self-regulated learning skills. The relationship between pre-service teachers' opinions about constructivist approach and their self-regulated learning skills was investigated. The one group pre-test-post-test design was used in the study. The sample of the study was 58 pre-service teachers from Hacettepe University, Department of Science Education, who were attending chemistry experiments at Science Teaching Laboratory Applications II Course. Self-regulated Learning Skills Scale developed by Turan and Demirel (2010) and Opinion Scale of Constructivist Approach for Science Teachers developed by Balım, Kesercioğlu, Evrekli ve İnel (2009) were used as data collection tools. At the end of the study, it was determined that constructivist chemistry laboratory applications caused a positive increase in pre-service teachers' self-regulated learning skills and opinions about constructivist approach. Also, there was a positive relationship between pre-service teachers 'self-regulated learning skills and opinions about constructivist approach that was observed.
\end{abstract}

Key words: constructivist approach, self-regulated learning, chemistry laboratory applications, preservice teachers.

\section{Introduction}

Laboratory activities are commonly used in science education after science education has started to be applied in educational institutions systematically (Hofstein, 2004). Laboratories are very effective environments, which help students construct concepts in their minds and develop their questioning and problem solving skills when they are designed appropriately. Attitudes of students towards the discipline or subject as well as psychomotor and observation skills can be improved thanks to laboratory activities (Gunstone, 1991; Tobin, 1990; as cited in Hofstein, 2004).

Despite curriculum renewals in time, studies reveal that laboratory practices are not performed very efficiently. Students generally work in the laboratory like technicians and focus on laboratory activities like a cookbook, and do not discuss hypotheses, test and make experimental errors (Ar1 \& Bayram, 2012). In fact, there should be problem presentation, a way to solve the problem, hypothesize, testing hypothesis, and generalization stages in a well-designed labo- 
Emine ERDEM, Sinem DINÇOL ÖZGÜR, Zeki BAYRAM, Özge ÖZYALÇIN OSKAY, Şenol ŞEN. Self-Regulated Learning in Constructivist Approach Based Science Laboratory Practices and Opinions on Constructivist Approach

PROBLEMS

OF EDUCATION

IN THE $21^{\text {st }}$ CENTURY

Volume 59, 2014

ratory class. Students can compile and analyse data, and find partial or complete solutions for problems in such laboratory classes. Students may not find the right solution and be required to search for an alternative solution. Students find solutions to problems by using their own information and concepts, and by exchanging their views with other students views until they reach a general idea in both cases. This approach is consistent with constructivist learning theory in which the learner participates in the learning process actively and he/she is responsible for his/ her own learning (Schneider, Krajcik, Marx \& Soloway, 2002; Shiland, 1999; Staver, 1998; Treagust, 1991). According to the theory, an individual correlates information obtained as a result of his/her interaction with surrounding cases and objects with his/her former information, and then, constructs it as new information (Kelly, 1997; Osborne, 1996; Shiland, 1999; Treagust, 1991). Therefore, inquiry based, problem based, project based, and argumentation based laboratory activities depending on the constructivist learning model have recently been used commonly.

Accordingly, a self-regulated learning skill is one of the required characteristics of students who will participate in constructivist practices. A self-regulated learning concept can be defined as an efficient and constructivist process in which learners participate in their own learning motivationally, cognitively, and meta-cognitively by setting a target or targets, monitoring their learning, and controlling their motivation and cognitions (Pintrich, 2000; Schunk, 2005; Zimmerman, 1986, 1989). According to Zimmerman (1998), self-regulation is not a cognitive skill like intelligence and not an academic skill like proficiency or studying; it is a selfmanagement process turning intellectual skills of learners into academic skills. According to Pintrich (2000), it is an efficient process in which learners set targets for learning and attempt to control, regulate, and observe their cognitions, behaviours, and motivations while reaching this target.

According to Schaw, Crippen and Hartly (2006), constructivist teaching methods and techniques develop intellectual abilities and self-regulated learning skills of students such as problem solving and critical thinking as in inquiry based learning, cooperative learning, etc. Within the scope, this study aims to determine the effects of constructivist approach based in chemistry laboratory practices on pre-service science and technology teachers' self-regulated learning skills and views for constructivist approach. Moreover, correlation between pre-service teachers' opinions for constructivist approach and self-regulated learning skills are examined.

\section{Problem of Research}

With this study, it was aimed to determine the effect of constructivist chemistry laboratory on science and technology pre-service teachers' opinions about constructivist approach and their self- regulated learning skills. Also, the relationship between pre-service teachers' opinions about constructivist approach and their self-regulated learning skills was investigated. In this aspect, the following four questions were attempted to be answered:

1) Is there a statistically significant difference between pre-test and post-test scores related to the following sub-dimensions of self-regulated learning skills scale of pre-service science and technology teachers: "motivation and action to learning", "planning", "strategy using and assessment", and "lack of self-directedness"?

2) Is there a statistically significant difference between pre-test and post-test (total) scores of self-regulated learning skills scale of pre-service science and technology teachers?

3) Is there a statistically significant difference between pre-test and post-test scores of opinion scale of constructivist approach of pre-service science and technology teachers?

4) Is there a statistically significant relationship between pre-service science and technology teachers' constructivist approach opinions and self-regulated learning skills? 


\section{Methodology of Research}

This research employs the one-group pre-test-post-test design. In this design, a single group is measured or observed not only after being exposed to a treatment of some sort, but also they are also observed and measured before (Fraenkel \& Wallen, 2006). The success of the treatment is determined by comparing pre-test and post-test scores (Gay \& Airasian, 2000).

\section{Sample of Research}

The sample for the research consisted of 58 pre-service teachers from the Department of Science Education at, Hacettepe University in Turkey, who attended chemistry laboratory practices studies conducted in accordance with Science Teaching Laboratory Practices II in the spring semester of the 2012-2013 academic year. They took theoretical lessons in the fall semester in Science Teaching Laboratory Practices I.

\section{Instruments}

In the study "Self-regulated Learning Skills Scale" and "Constructivist Approach Opinion Scale" were used as data collection tools.

Self-regulated Learning Skills Scale (SRLSS): "Self-regulated Learning Skills Scale" was developed by Turan and Demirel (2010) for determining self-regulated learning skills of pre-service teachers was used. The scale is a 5 point Likert scale comprised by 4 sub-dimensions and 41 items. The lowest point that is possible on the scale is 41 while the highest is 205. Sub-dimensions of the scale are "Motivation and Action to Learning (7 items)", "Planning (8 items)", "Strategy Using and Assessment (19 items)", and "Lack of Self-directedness (7 items)".

In the scale, the percentages of sub-dimensions in explaining total variance are as follows: the first dimension is $18.36 \%$, the second one is $16.94 \%$, the third one is $11.95 \%$, and the fourth one is $7.87 \%$, with a total of $47.10 \%$. Cronbach's alpha reliability coefficients for sub-dimensions of the scale are calculated respectively as $0.88,0.91,0.83,0.76$; and 0.91 for all articles (Turan and Demirel, 2010).

Opinion Scale of Constructivist Approach for Science Teachers (OSCA): This scale, which was developed by Balım, Kesercioğlu, Evrekli and İnel (2009) for determining constructivist approach opinions of pre-service teachers was used. The scale is a 5 point Likert scale comprised by a single dimension and 30 items. Cronbach's alpha reliability coefficient of the scale was calculated to be 0.97 .

\section{The Process for Constructivist Approach Based Laboratory Practice}

The subsequent steps that were done in science laboratory practices class are as follows:

1. Pre-service teachers take theoretical lessons in the fall semester in Science Teaching Laboratory Practices I. Constructivist approach is also mentioned, and constructivist approach based activity examples (3E, 5E, 7E, questioning based teaching, etc.) are promoted in these theoretical lessons.

2. Curriculum attainments of science and technology class are distributed to the preservice teachers in the Science Teaching Laboratory Practices II. Attainments on a subject selected from the "substance and transformation" (chemistry weighted) unit in the science and technology syllabus are given to the pre-service teachers, and they are asked to prepare a worksheet that includes experimental activities related to the given attainments. Pre-service teachers present their worksheets to the lesson supervisor within given time period, and re-prepare these worksheets according to the feedback that is given. 
Emine ERDEM, Sinem DINÇOL ÖZGÜR, Zeki BAYRAM, Özge ÖZYALÇIN OSKAY, Şenol ŞEN. Self-Regulated Learning in Constructivist Approach Based Science Laboratory Practices and Opinions on Constructivist Approach

EMS

OF EDUCATION

IN THE $21^{\text {st }}$ CENTURY

Volume 59, 2014

3. Experimental activities mentioned in these worksheets are applied in the laboratory.

4. Feedback is taken from both pre-service teachers and the lesson supervisor during the practices, and then the worksheets are reviewed and take their final shape.

5. Pre-service teachers undergo a self-critique with regards to designing and presenting constructivism based laboratory activities at the end of the practices.

\section{Data Analysis}

In this research, data analysis was carried through descriptive statistics (mean and standard deviation values) and paired samples t-test. Also Pearson correlation coefficient was used to evaluate the correlation between constructivist approach opinions and self-regulated learning skills of pre-service teachers. The level of significance is defined as 0.05 in data analysis

\section{Results of Research}

The results were examined in line with the study's research questions. In relation to the first question of the study, Table 1 shows the results of the paired samples t-test performed in order to find the significance of the difference between pre-test and post-test mean scores related to the sub-dimensions of self-regulated learning skills scale of pre-service science and technology teachers.

Table 1. Paired samples t-test results of self-regulated learning skills scale subdimensions' pre-test and post-test mean scores.

\begin{tabular}{|c|c|c|c|c|c|c|c|}
\hline SRLSS Sub-dimensions & & N & $\bar{X}$ & sd & df & $\mathrm{t}$ & $\mathrm{p}$ \\
\hline \multirow{2}{*}{ Motivation and Action to Learning (1) } & Pre-test & 58 & 27.15 & 2.97 & \multirow{2}{*}{57} & \multirow{2}{*}{-2.143} & \multirow{2}{*}{0.036} \\
\hline & Post-test & 58 & 28.00 & 3.68 & & & \\
\hline \multirow{2}{*}{ Planning (2) } & Pre-test & 58 & 30.53 & 4.37 & \multirow{2}{*}{57} & \multirow{2}{*}{-3.48} & \multirow{2}{*}{0.001} \\
\hline & Post-test & 58 & 32.43 & 4.34 & & & \\
\hline \multirow{2}{*}{ Strategy Using and Assessment (3) } & Pre-test & 58 & 72.02 & 9.85 & \multirow{2}{*}{57} & \multirow{2}{*}{-4.23} & \multirow{2}{*}{0.000} \\
\hline & Post-test & 58 & 76.60 & 8.55 & & & \\
\hline \multirow{2}{*}{ Lack of Self-directedness (4) } & Pre-test & 58 & 26.18 & 3.15 & \multirow{2}{*}{57} & \multirow{2}{*}{-3.52} & \multirow{2}{*}{0.001} \\
\hline & Post-test & 58 & 27.74 & 2.97 & & & \\
\hline
\end{tabular}

It was found out that constructivist approach based chemistry laboratory practices led to a significant increase in all sub-dimensions scores of self-regulated learning skills scale of pre-service teachers $\left(\mathrm{t}_{(57,1 . \text { dimension })}=-2.143 ; \mathrm{t}_{(57,2 \text {. dimension })}=-3.48 ; \mathrm{t}_{(57,3 \text {. dimension })}=-4.23 ; \mathrm{t}_{(57,4 \text {. dimension })}\right.$ $=-3.52, \mathrm{p}<0.05)$. The mean score of motivation and action to learning sub-dimension increased from 27.15 to 28.00 ; the mean score of planning sub-dimension increased from 30.53 to 32.43 ; the mean score of strategy using and assessment increased from 72.02 to 76.60 , and the mean score of lack of self-directedness increased from 26.18 to 27.74 .

These findings indicate that constructivist approach based chemistry laboratory practices have an important effect on the development of pre-service teachers' skills related to motivation and action to learning, planning, strategy using and assessment, and lack of self-directedness sub-dimensions.

With regard to the second question of the study, Table 2 shows the results of the paired samples t-test performed in order to find the significance of the difference between pre-test and post-test mean scores of self-regulated learning skills scale of preservice teachers. 
Emine ERDEM, Sinem DINÇOL ÖZGÜR, Zeki BAYRAM, Özge ÖZYALÇIN OSKAY, Şenol ŞEN. Self-Regulated Learning in Constructivist Approach Based Science Laboratory Practices and Opinions on Constructivist Approach

Table 2. Paired samples t-test results of self-regulated learning skills scale total pre-test and post-test mean scores.

\begin{tabular}{lllllll}
\hline SRLSS & $\mathbf{N}$ & $\bar{X}$ & $\mathbf{s d}$ & $\mathbf{d f}$ & $\mathbf{t}$ & $\mathbf{p}$ \\
\hline Pre-test & 58 & 155.89 & 18.49 & 57 & -4.29 & 0.000 \\
\hline Post-test & 58 & 164.74 & 18.17 & & & \\
\hline
\end{tabular}

It was determined that constructivist approach based chemistry laboratory practices led to a significant increase in the self-regulated learning skills scores of pre-service teachers $\left(t_{(57)}\right.$ $=-4.29, \mathrm{p}<0.05)$. The mean scores of self-regulated learning skills of pre-service teachers increased from 155.89 to 164.74 . This finding reveals that constructivist approach based chemistry laboratory practices have an important effect on the development of pre-service teachers' self-regulated learning skills.

In relation to the third questions of the study, Table 3 shows the results of the paired samples t-test performed in order to find the significance of difference between pre-test and post-test mean scores of the opinion scale of constructivist approach of pre-service teachers.

Table 3. Paired samples t-test results of constructivist approach opinion scale total pre-test and post-test mean scores.

\begin{tabular}{lllllll}
\hline OSCA & $\mathbf{N}$ & $\bar{X}$ & $\mathbf{s d}$ & $\mathbf{d f}$ & $\mathbf{t}$ & $\mathbf{p}$ \\
\hline Pre-test & 58 & 127.77 & 14.06 & 57 & -2.117 & 0.039 \\
\hline Post-test & 58 & 131.72 & 12.93 & & & \\
\hline
\end{tabular}

It was found out that constructivist approach based chemistry laboratory practices led to a significant increase in the constructivist approach opinion scores of pre-service teachers $(t(57)$ $=-2.117, \mathrm{p}<0.05)$. The mean scores of constructivist approach opinions of pre-service teachers increased from 127.77 to 131.72 . This finding indicates that constructivist approach based chemistry laboratory practices positively affect constructivist approach opinions of pre-service teachers.

Regarding the fourth question of the study, Table 4 shows the correlation analysis result between the scores obtained by pre-service teachers from the opinion scale of constructivist approach and self-regulated learning skills scale.

Table 4. Correlation analysis results of constructivist approach opinion scale scores and self-regulated learning skills scale scores.

\begin{tabular}{llll}
\hline & & OSCA & SRLSS \\
\hline & & & \\
\hline \multirow{3}{*}{ OSCA } & Pearson Korelasyon $(r)$ & 1.000 & $.465^{* *}$ \\
& Sig. (2-tailed) &. & .000 \\
& $N$ & 58 & 58 \\
\hline \multirow{3}{*}{ SRLSS } & Pearson Korelasyon ( $r$ ) & $.465^{* *}$ & 1.000 \\
& Sig. (2-tailed) & .000 &. \\
& $N$ & 58 & 58 \\
\hline
\end{tabular}


Emine ERDEM, Sinem DINÇOL ÖZGÜR, Zeki BAYRAM, Özge ÖZYALÇIN OSKAY, Şenol ŞEN. Self-Regulated Learning in Constructivist Approach Based Science Laboratory Practices and Opinions on Constructivist Approach

BLEMS

OF EDUCATION

IN THE $21^{\text {st }}$ CENTURY

Volume 59, 2014

As a result of examining Table 4, it can be seen that there is a medium-level, positive, and significant correlation between constructivist approach opinions and self-regulated learning skills of pre-service teachers $(\mathrm{r}=0.465 ; \mathrm{p}>0.05)$. Accordingly, it can be said that the more the self-regulated learning skills of pre-service teachers increase, the more the constructivist approach opinions increase positively.

\section{Discussion}

The study aimed to determine the effects of constructivist approach based chemistry laboratory practices on self-regulated learning skills and the constructivist approach opinions of pre-service teachers. In addition, the correlation between self-regulated learning skills and constructivist approach opinions of pre-service teachers were examined.

Constructivist approach based chemistry laboratory practices led to a significant increase in "motivation and action to learning", "planning", "strategy using and assessment", and "lack of self-directedness" sub-dimension scores and in all of the total scores of pre-service science and technology teachers' self-regulated learning skills scale. This increase shows that constructivist approach based chemistry laboratory practices can affect self-regulated learning skills of students that can control self-learning. Methods and strategies including the process of active learning, and teaching styles such as learning with a project, learning via discussion, programmed learning, etc. affect self-regulated skills of students. Positive effects have been found in self- regulated skills of students who use their own knowledge and concepts, share their views with friends in a learning environment in which such methods and strategies are used (Altun \& Erden, 2013; Chen, 2002; Güvenç, 2011, Schunk \& Zimmermann, 1998; Ryser, Beeler \& McKenzie, 1995; Yüksel, 2013;). Ryser, Beeler and McKenzie (1995) found in their study performed in computer aided constructivist learning environment that there were significant increases in self-behavioural management, making logical decisions, and self-regulated learning skills of students. This study supports the increase in self-regulated learning skills of students determined in constructivist approach based chemistry laboratory practices. In studies conducted for self-regulated skills, generally studies about self- regulation sub- dimensions, and the relation between self-regulated learning strategies of students and academic success can be found (Haşlaman \& Aşkar, 2007; Pintrich \& de Groot, 1990; Sungur \& Güngören, 2009; Usta \& Bozpolat, 2014; Zimmermann, 1990).

According to the results of research findings, it can be seen that the constructivist approach based chemistry laboratory practices lead to positive increase in the views of preservice science and technology teachers for constructivist approach. Pre-service teachers had an opportunity to practice constructivist approach based activities $(3 \mathrm{E}, 5 \mathrm{E}, 7 \mathrm{E}$, inquiry based teaching, etc.), that they theoretically learned in Science Teaching Laboratory Practices I, and in Science Teaching Laboratory Practices II. It can be considered that practicing the approach learned theoretically in a class environment will improve pre-service teachers opinions of the constructivist approach. It has been determined that laboratory practices conducted according to constructivist approach can positively affect academic success, scientific process skills, and laboratory performances of students (Ar1 \& Bayram, 2012; Driver \& Oldham, 1986; Hand \& Treagust, 2010; Malatyali \& Yilmaz, 2010). Moreover, it has been discovered that constructivist approach ensures a more efficient of learning for students (Schneider, Krajcik, Marx ve Soloway, 2002; Yurdakul, 2008), and activities developed in constructivist learning environment lead to a positive increase in their views for constructivist approach (Özgen \& Alkan, 2012).

Within the scope of research, a mid-range positive level and significant relation was found in correlation analysis made for determining the relation between views of preservice science and technology teachers on constructivist approach and their self-regulated learning skills. In constructivist approach based laboratory practices, the increase in self-regulated learning skills of students explains a $21 \%\left(\mathrm{r}^{2}\right)$ increase on how the students view constructivist approach. It can be seen that constructivist approach practices prompt self-regulated learning skills of 
pre-service teachers. The constructivist learning approach and self-regulated learning concept complement each other well. Learners play an active role in the learning process in constructivist learning approach and they are responsible for their own learning. Learners determine their own learning targets and process in self-regulated learning and they control their own learning. It is stressed in literature that learners construct information as a result of following the methods of constructivist learning approach and making changes to their ideas by reviewing their information through self-regulation (Arslan, 2007; Yurdakul, 2008). Similar studies could not be found in literature, therefore more studies supporting the results could not be presented.

\section{Conclusions}

Departing from research findings, it can be concluded that chemistry laboratory practices, which are arranged according to constructivist approach, lead to a significant increase in self-regulated learning skills and constructivist approach opinions of pre-service teachers. Accordingly, the following suggestions should be taken into consideration:

- Since lifelong learning and self-learning concepts remain at the forefront of modern education, pre-service teachers need to know how to practice the self-regulation method for managing and directing their exercises.

- In order to ensure better a comprehension of constructivist approach by pre-service teachers, practices can take a bigger part instead of giving only theoretical information and teaching the method; thus, pre-service teachers are allowed to maintain a positive attitude and opinions using constructivist approach.

- Laboratory practices should be designed in a way so that students can improve their self-regulated learning skills, practice information, and easily in their minds.

- Literature includes studies analysing opinions for self-regulated learning and constructivism. However, research analysing the correlations between constructivist laboratory practices and self-regulated learning cannot be found in current literature. Further research is needed in order to better explain the correlation.

\section{References}

Altun, S., \& Erden, M. (2013). Self-regulation based learning strategies and self-efficacy perception as predictors of male and female students'mathematics achievement. Procedia-Social and Behavioral Sciences, 106, 2354-2364.

Arı, E., \& Bayram, H. (2012). The impact of constructivism based general chemistry laboratory practices on students' the achievement, scientific process skills and laboratory performance. Western Anatolia Journal of Educational Science, 3 (6), 1-18.

Arslan, M. (2007). Constructivist approaches in education. Ankara University, Journal of Faculty of Educational Sciences, 40 (1), 41-61.

Balım, A. G., Kesercioğlu, T., Evrekli, E., \& İnel, D. (2009). Constructivist approach opinion scale for pre- service science teachers: A study of validity and reliabilitiy. Inonu University Journal of the Faculty of Education, 10 (1), 79-92.

Chen, C. S. (2002). Self-regulated learning strategies and achievement in an introduction to information systems course. Information Technology, Learning, and Performance Journal, 20 (1), 11-25.

Driver, R., \& Oldham, V. (1986). A Constructivist approach to curriculum development in science. Studies in Science Education, 13 (1), 105-122.

Güvenç, H. (2011). Effect of study diaries on sixth graders' self-regulated learning. Hacettepe University Journal of Education, 41, 206-218.

Fraenkel, J. R., \& Wallen, N. E. (2006). How to design and evaluate research in education. Sixth Edition, Boston: McGraw- Hill.

Gay, L. R., \& Airesian, P. (2000). Educational research: competencies for analysis and application. Sixth Edition, Upper Saddle River, NJ: Prentice-Hall, Inc.

Hand, B., \& Treagust, D. F. (2010). Student achievement and science curriculum development using a constructive framework. School Science and Mathematics, 91 (4), 172-176. 
Emine ERDEM, Sinem DINÇOL ÖZGÜR, Zeki BAYRAM, Özge ÖZYALÇIN OSKAY, Şenol ŞEN. Self-Regulated Learning in Constructivist Approach Based Science Laboratory Practices and Opinions on Constructivist Approach

PROBLEMS

OF EDUCATION

IN THE $21^{\text {st }}$ CENTURY

Volume 59, 2014

Haşlaman, T., \& Aşkar, P. (2007). Investigating the relationship between self-regulated learning strategies and achievement in a programming course. Hacettepe University Journal of Education, 32, $110-122$

Hofstein, A. (2004). The laboratory in chemistry education: Thirty years of experience with developments, implementation and research. Chemistry Education Research and Practice, 5 (3), 247-264.

Kelly, G. J. (1997). Research traditions in comparative context: A philosophical challenge to radical constructivism. Science Education, 81 (3), 355-375.

Malatyali, E., \& Yilmaz, K. (2010). The importance of concepts in the constructiviist learning process: An examination of concepts from pedagogical angle. The Journal of International Social Research, 3 (14), 321-332.

Osborne, J., F. (1996). Beyond constructivism. Science Education, 80 (1), 53-82.

Özgen, K., \& Alkan, H. (2012). An analysis of student views on activities developed according to learning styles within a constructivist learning environment. Dicle University Journal of Ziya Gokalp Faculty of Education, 18, 239-258.

Pintrich, P. R., \& de Groot, E. V. (1990). Motivational and self-regulated learning components of classroom academic performance. Journal of Educational Psychology, 82 (1), 33-40.

Pintrich, P. R. (2000). The role of goal orientation in self-regulated learning. In M. Boekaerts, P. Pintrich, \& M. Zeidner (Eds.), Handbook of self-regulation (pp. 451-502). Academic Press, San Diego, USA.

Ryser, G., Beeler, J. E., \& McKenzie, C. M. (1995). Effects of a computer-supported international learning environment (CSILE) on students' self-concept, self-regulatory behavior and critical thinking ability. Journal of Educational Computing Research, 13 (4), 375-385.

Schneider, R. M. Krajcik, J., Marx, R. W., \& Soloway, E. (2002). Performance of students in projectbased science classrooms on a national measure of science achievement. Journal of Research in Science Teaching, 39 (5), 410-422.

Schraw, G., Crippen K. J., \& Hartley, K. (2006). Promoting self-regulation in science education: Metacognition as part of a broader perspective on learning. Research in Science Education, 36, $111-139$.

Schunk, D. H. (2005). Self-regulated learning: The educational legacy of Paul R. Pintrich. Educational Psychologist, 40 (2), 85-94.

Schunk, D. H., \& Zimmermann, B. J. (1998). Computing technologies as sites for developing self-regulated learning. In P. H. Winne \& D. B. Stockley (Eds.), Self-regulated learning, from teaching to self-reflective practice, (pp: 106-137). New York: Guilford.

Shiland, T. W. (1999). Constructivism: The implications for laboratory work. Journal of Chemical Education, 76 (1), 107-108.

Staver, J. R. (1998). Constructivism: Sound theory for explicating the practice of science and science teaching. Journal of Research in Science Teaching, 35 (5), 501-520.

Sungur, S., \& Güngören, S. (2009). The role of classroom environment perceptions in self-regulated learning and science achievement. Elementary Education Online, 8 (3), 883-900.

Treagust, D. F. (1991). Student achievement and science curriculum development using a constructive framework. School Science and Mathematics, 91 (4), 172-176.

Turan, S., \& Demirel, Ö. (2010). The relationship between self-regulated learning skills and achievement: a case from Hacettepe University medical school. Hacettepe University the Journal of Education, $38,279-291$.

Usta, G., \& Bozpolat, E. (2014). An assessment of education faculty students' views on their self-regulated learning skills. Procedia-Social and Behavioral Sciences, 116, 1620-1625.

Yurdakul, B. (2008). Contribution of constructivist learning approach to constructing knowledge in sociocognitive context. Balıkesir University the Journal of Social Sciences Institute, 11 (20), 39-67.

Yüksel, I. (2013). The predictive power of instructional style preferences for self-regulation skill levels, Dicle University Journal of Ziya Gokalp Faculty of Education, 20, 212-229.

Zimmerman, B. J. (1986). Development of self-regulated learning: Which are the key subprocesses? Contemporary Educational Psychology, 16, 307-313.

Zimmerman, B. J. (1989). A social cognitive view of self-regulated academic learning. Journal of Educational Psychology, 81 (3), 329-339.

Zimmermann, B. J. (1990). Self-regulated learning and academic achievement: An overview. Educational Psychologist, 25 (1), 3-17. 
Emine ERDEM, Sinem DINÇOL ÖZGÜR, Zeki BAYRAM, Özge ÖZYALÇIN OSKAY, Şenol ŞEN. Self-Regulated Learning in Constructivist Approach Based Science Laboratory Practices and Opinions on Constructivist Approach

Zimmerman, B. J. (1998). Academic studying and the development of personal skill: A self-regulatory perspective. Educational Psychology, 33, 73-86.

Advised by Martin Bilek, Hradec Kralove University, Czechia

Received: January 31, 2014

Accepted: March 26, 2014

\begin{tabular}{|ll|}
\hline Emine Erdem & $\begin{array}{l}\text { PhD., Associate Professor, Hacettepe University, Ankara, Turkey. } \\
\text { E-mail: erdeme@hacettepe.edu.tr }\end{array}$ \\
\hline Sinem Dinçol Özgür & $\begin{array}{l}\text { PhD., Research Assistant, Hacettepe University, Ankara, Turkey. } \\
\text { E-mail: sinemdincol@hacettepe.edu.tr }\end{array}$ \\
\hline Zeki Bayram & $\begin{array}{l}\text { PhD., Assistant Professor, Hacettepe University, Ankara, Turkey. } \\
\text { E-mail: zeki.bayramm@gmail.com }\end{array}$ \\
\hline Özge Özyalçın Oskay & PhD., Associate Professor, Hacettepe University, Ankara, Turkey. \\
\hline E-mail: ozge@hacettepe.edu.tr \\
\hline Şenol Şen & PhD., Research Assistant, Hacettepe University, Ankara, Turkey. \\
& E-mail: schenolschen@gmail.com \\
\hline
\end{tabular}

